\title{
CREATION OF WINTER WHEAT SOURCE MATERIAL WITH INCREASED ADAPTIVE POTENTIAL TO ADVERSE ENVIRONMENTAL CONDITIONS
}

\author{
Lida Khomenko \\ Institute of Plant Physiology and Genetics \\ of the National Academy of Sciences of Ukraine \\ 31/17, Vasylkivska str., Kyiv, Ukraine, 03022 \\ lidole@ukr.net
}

\begin{abstract}
The goal until the last day was to create a new sort with high indicators of productivity, adaptability and quality of grain on the basis of the directed selection process and comprehensive study of hybrid material on field and laboratory estimations.

Creation of initial material with high productivity, adaptability and grain quality by directed selection and hybrid material comprehensive study is described. General scientific, special genetic, field, laboratory methods, morphological analysis and statistical methods were used in the research. Given that the weight of grain from 1 ear is a marker in breeding for high yield $(r=0.53)$, the largest (50\%) positive transgressions were in $F_{1}$ hybrids using new genetic plasma varieties. Among hybrid populations $F_{2}, F_{3}$ and $F_{4}$, selection value is represented by hybrid populations 4971 and 4976, which have the lowest stress resistance $(-16.1,-18.6)$ and variation $(16.9,19.9)$ and the highest genetic stability $(50.0,50.2)$ and homeostaticity $(19.1,14.3)$, respectively. Among Control, Preliminary and Competitive tests, lines UK2621/18 and UK9855/18 have high stress resistance (-4.7, -5.8), homeostaticity (1416.0, 1008.0) and low variability $(2.6 \%, 3.5 \%)$, respectively. They are the most adaptive and malleable to average and adverse environmental conditions. Line UK1182/17, which in 2020 was submitted for consideration to the State variety testing as «Blahovishchenska» (Kiev, Ukraine), was created using the purposeful method of pedigree in each link of selection. It has high adaptability, resistance to lodging, major diseases, high average yield $(90.8 \mathrm{c} / \mathrm{ha}$ ), and grain quality - it is strong wheat (protein amount $13.5-14.0 \%$, gluten $30-35 \%$ ). Pedigree is the most effective method of continuous individual selection, which allows creating source material with high productivity, resistance to disease and adverse environmental factors.
\end{abstract}

Keywords: T. aestivum L., genotypes, variety, genetic potential, harvest, pedigree method, adaptation.

DOI: 10.21303/2504-5695.2021.002188

\section{Introduction}

Even 20-30 years ago, the yield of winter wheat at the level of $100 \mathrm{c} /$ ha was considered unattainable, and today it is a reality. For the first time in the history of Ukraine, wheat varieties of the Institute of Plant Physiology and Genetics of the National Academy of Sciences of Ukraine (Kyiv, Ukraine) reached 120-140 c/ha [1], and this is not the limit. Potential yield of winter wheat is the maximum possible, which is determined by the biological and genetic capabilities of the plant and the efficiency of photosynthetic active radiation in the Forest-Steppe and Steppe zones is $160-200 \mathrm{c} /$ ha according to $[2,3]$.

Under favorable weather conditions, scientifically sound methods of crop formation management make it possible to increase the degree of realization of the biological potential of zoned and promising varieties of winter wheat from $25-30 \%$ to $59-60 \%$. In addition, weather factors affect yield fluctuations over the years up to $45-50 \%$ in each soil and climatic zone of Ukraine, which creates the preconditions for dual use of each hectare of crop $[4,5]$.

The analysis of climate data of Ukraine for the last 10 years (until 2010) showed that the yield of winter wheat was lower than the average efficiency of the climatic potential of $0.2-0.5$ in a large area of Ukraine (Central and Eastern Forest-Steppe). Scientists have proven that the climatic component still does not require changes in adaptation strategies [6]. The importance of climate in fluctuations in yields is secondary and subordinates to anthropogenic strategy.

Today, in today's climate change, grain production strategies are changing. It is advisable to take into account its genetic potential and suitability for cultivation in specific soil and climatic conditions to achieve a high level of crop yield. As a science, breeding has accumulated a large number of materials, methods and techniques that take into account modern advances in scientific 
and technological progress. However, it is still laborious, hard work of breeders, which requires deep knowledge and practical skills to create a source material with high productivity, adaptability and grain quality.

The goal until the last day was to create a new sort with high indicators of productivity, adaptability and quality of grain on the basis of the directed selection process and comprehensive study of hybrid material on field and laboratory estimations.

\section{Materials and Methods}

The research was conducted in the Department of Plant Genetic Improvement of the Institute of Plant Physiology and Genetics (IFRG) of the National Academy of Sciences of Ukraine on the basis of the Experimental Agricultural Production of the Institute (Glevakha town, Vasylkiv district, Kyiv region, Ukraine).

The material of the experiment was varietal samples, hybrids, hybrid populations and lines of winter wheat nurseries of hybrid, control, preliminary and competitive testing. Experimentation, harvesting and accounting of samples, sown in nurseries of various tests, were carried out according to the method of examination of cereal plant varieties for suitability for distribution in Ukraine [7]. The national standard variety «Yednist» was used as the yield standard. Repetition of experiments - 1-4 times (hybrid populations were bred in 1-fold repetition of the Control test, lines in 3-4 times - Preliminary and Competitive testing).

The study was aimed at improving hybridization systems and creating source material in the field using conventional technology for growing winter cereals. The sowing was carried out in the optimal time for the zone: September 17-27. The systematic method of site placement was used in the work [7].

The evaluation of overwintering of soft winter wheat selection material for frost and winter hardiness in the field was performed on a 9-point scale of overwintering according to the method of Ryabchun [8] and State Standard «Winter wheat» [9]. The evaluation of the resistance of culture samples to damage by pathogens was performed on a natural background according to the international scale, proposed in [10].

The degree of dominance of quantitative traits in $F_{1}$ hybrids was determined by the formula of [11]. Transgressions and their degree on the basis of productivity in hybrids were determined by the method of Orlyuk [2]. The selection of hybrid material for obtaining homozygous lines was performed by the method of pedigree $[12,13]$. In the areas of hybrid populations $F_{2}-F_{4}$ of control test, the selection of lines on such valuable traits as tillering of plants, ear size was performed visually. In the phase of milk-wax ripeness, the best 200 ears were selected according to the estimates of short-stemmedness, productivity and resistance of plants to lodging. Bundles of hybrid populations $F_{2}, F_{3}$ and $F_{4}$ were weighed and rejected by the weight of a bundle of 100 ears. Only bundles of the second and third generation with double rejection by grain weight were threshed in the population. The bundles of $\mathrm{F}_{4}$ ears were threshed individually. The evaluation of yield, stress resistance, genetic flexibility, coefficient of variation of the source material was performed according to the method of [14], and evaluation of homeostaticity and selection value was performed according to the method described [15].

The hybrid material of $F_{5}$ and $F_{6}$ of 100 or 200 ears/row was sown in the areas of the Comparative Test. The study was performed on 10-25 combinations. Research methods:

- general scientific metods - working hypothesis, experiment, observation, analysis;

- special methods - genetic, field, laboratory analyses, method of morphological analysis;

- mathematical and statistical methods variation, regression and analysis of variance. The statistical processing of the results was performed according to the method of Gupta and Kapoor [16] using Atte Stat software.

Meteorological conditions. Agrometeorological actual and average long-term indicators of weather conditions were used according to the weather archive from the website «Weather and Klimat» [17].

The analysis of climatic conditions in 2017-2020 showed that the duration of active vegetation of winter wheat in general was 170-175 days, which is 20-35 days shorter than usual (190- 
210 days). During the three vegetation cycles of winter wheat development, the average air temperature ranged from $+8.6{ }^{\circ} \mathrm{C}(2017 / 18)$ to $9.6^{\circ} \mathrm{C}(2019 / 20)$ (Fig. 1).

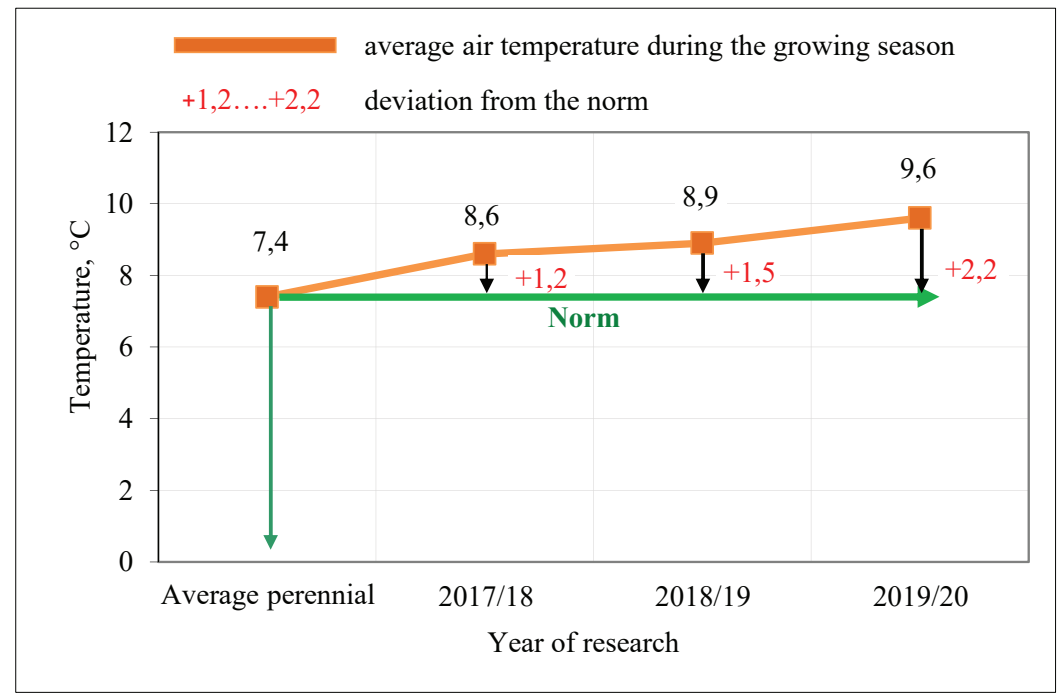

Fig. 1. The air temperature during the vegetation cycle of winter wheat during 2017-2020

The obtained data indicate that during the last three years the active vegetation of the crop took place under conditions of elevated temperature, where the actual average air temperature annually exceeded the norm from $+1.2{ }^{\circ} \mathrm{C}$ in $2017 / 18$ to $+2.2{ }^{\circ} \mathrm{C}$ in $2019 / 20$ with a tendency to increase.

In recent years, the conditions of autumn hardening of winter crops have changed significantly. The unstable nature of winter weather causes the continuation of physiological processes in the body of plants, including the growth of the growth cone, which leads to a decrease in frost and winter hardiness of wheat. Therefore, constantly monitoring the state of hardening and overwintering of winter wheat is necessary.

Precipitation fell quite unevenly and locally in intensity during the last three vegetation cycles of winter wheat (Fig. 2).

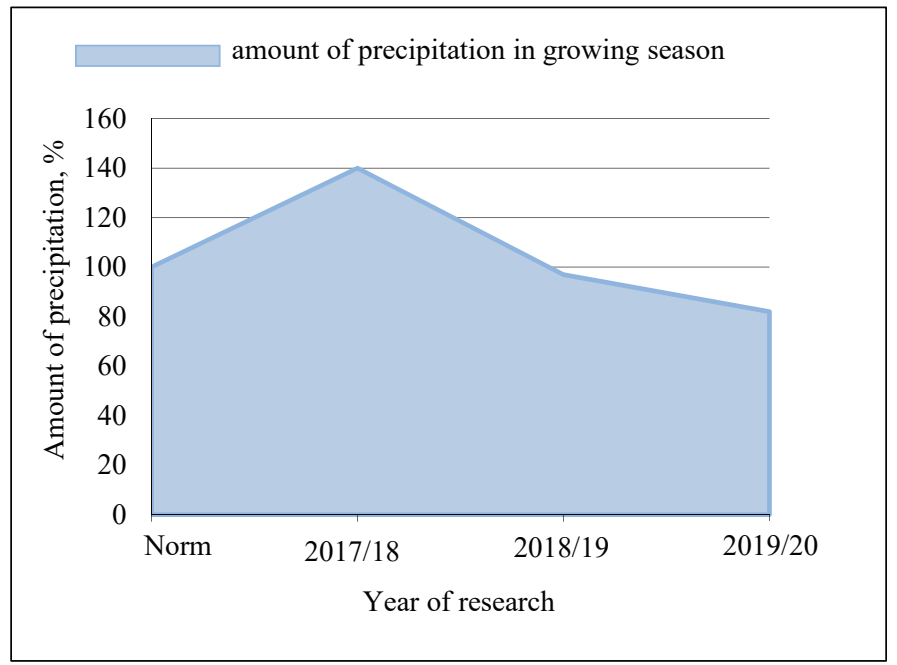

Fig. 2. The amount of precipitation that fell during the growing cycle of winter wheat in 2017-2020

During the winter wheat vegetation for the last 3 years, droughts were observed annually during high average daily air temperatures of $(+20)-(+25){ }^{\circ} \mathrm{C}$, both air temperatures in April-June 
of 2018 and soil temperatures in June of 2019 and in autumn and summer of 2020. The data show that most precipitation fell in $2017 / 18-708 \mathrm{~mm}$ during the growth of winter wheat, which was $140 \%$ of the norm with a decrease in their number in subsequent years to $415 \mathrm{~mm}$ during 2019/20, which was $82 \%$ of the norm.

Thus, the analysis of climatic conditions in 2017-2020 showed that the growing season of winter wheat took place at elevated temperatures, which caused a violation of the hardening of plants and a decrease in frost resistance. And insufficient soil moisture led to drought, which significantly reduced the yield of varieties with a low level of adaptability.

\section{Results and discussion}

According to many researchers [18], the contribution of selection in increasing crop yields is $30-70 \%$. The main method of selection for the creation of source material at the IFRG is intraspecific and interspecific hybridization.

In 2018-2020, hybridization involved varieties of domestic and foreign varieties (Ukraine, Germany, France, Avstria, USA, Bulgaria and others) with high productivity, complex stability, economically valuable traits that significantly exceed national standards and have a high degree of ecological plasticity and adaptability, as well as ecologically and geographically remote varieties from different countries of the world. We used simple, three-line, backcross and analyzing crosses to increase productivity and protein content. The average attachment of 1 ear as a whole according to the hybridization plan for 2018-2020 was $64.8 \%$, which indicates the compatibility of genetic systems, rates of development and phases of earing of parental components.

The population, formed by the planned hybridization of the required traits, is genetically valuable for selection when creating new varieties. However, the splitting of the selected valuable traits occurs differently in each new generation, so it is necessary to carry out the analysis with an emphasis on the effectiveness of selection [19,20]. It is known, that the selection is aimed at increasing productivity in recent years, so during the period of milk-wax ripeness in areas of $F_{1}$ hybrids 100 ears of each combination were cut. Spikelets were threshed, grain was weighed and the most productive populations were selected (Table 1).

Table 1

The grain weight of 100 ears of $F_{1}$ hybrids of winter wheat in 2018-2020

\begin{tabular}{|c|c|c|c|c|}
\hline \multirow{2}{*}{ Indicator } & \multicolumn{4}{|c|}{ Weight, $\mathrm{g}$} \\
\hline & 2018 & 2019 & 2020 & Average \\
\hline The average weight of grain from 100 spikelets, $g$ & $295.5 \pm 4.4$ & $269.3 \pm 3.9$ & $185.0 \pm 6.2$ & 249.9 \\
\hline The average weight of grain of selection from 100 spikelets, $g$ & $310.0 \pm 5.8$ & $279.1 \pm 4.9$ & $205.5 \pm 7.9$ & 264.8 \\
\hline Effectiveness of selection, $\%$ & 4.9 & 3.6 & 11.1 & 6.0 \\
\hline
\end{tabular}

Note: $S S D_{0.05}=13.9 ; S S D_{0.01}=21.1$

The average grain weights of 100 spikelets and 100 selected spikelets changed significantly during the study period. A significant difference in the $5 \%$ level of significance between the average grain weight of 100 spikelets and the selection of 100 spikelets was observed in 2018 and 2020.

Given that the weight of grain from 1 ear is a marker in the selection for high yields $(r=0.53)$ [21], this figure was calculated for $F_{1}$ hybrids of the harvest in 2018. When crossing contrasting parental genotypes in $F_{1}$ hybrids, their transgressive variability should be expected (desirable with a positive effect) (Table 2).

The obtained data show that the largest number $(50 \%)$ of positive transgressions were in $\mathrm{F}_{1}$ hybrids using new genetic plasma varieties. Grain weight of 1 ear has the highest degree of transgression $(28.9 \%)$ and complete dominance of the trait in the main crosses and in combinations of the special program $(25.0 \%)$ with over-dominance of the trait. The parameters of transgressive traits of productivity are highest in heterosis hybrids $[2,22]$.

It is especially important in the initial stages of the selection process to reject the selection material systematically. Therefore, the best 200 ears were selected in the areas of hybrid popula- 
tions $F_{2}-F_{4}$ in the phase of milk-wax ripeness. The yield of hybrid populations remaining as a result of targeted selection in 2018-2020 (Table 3).

Table 2

The positive transgressions on the basis of grain weight from 1 ear in $F_{1}$ hybrids with different degrees of dominance, 2018

\begin{tabular}{|c|c|c|c|c|c|c|}
\hline \multirow{2}{*}{ Direction crossing } & \multirow{2}{*}{$\begin{array}{c}\text { Number hybrid } \\
\text { combinations }\end{array}$} & \multicolumn{2}{|c|}{ Weight of 1 ear, $g$} & \multirow{2}{*}{$\%(+)$ of $\mathrm{Tg}$} & \multirow{2}{*}{ Degree of $\mathbf{T g}$} & \multirow{2}{*}{$h_{p}$} \\
\hline & & of the best father & of the hybrids & & & \\
\hline Main & 16 & $2.5-4.5$ & $2.8-3.5$ & 18.8 & 28.9 & 2.9 \\
\hline Backcross & 17 & $2.8-4.0$ & $2.8-3.6$ & 11.8 & 20.0 & 0.7 \\
\hline Simple and $\mathrm{BC}_{1}$ & 6 & $2.5-4.0$ & $2.7-3.7$ & 50.0 & 20.0 & -2.0 \\
\hline Special programm & 24 & $2.5-4.0$ & $2.3-3.7$ & 4.2 & 25.0 & 1.7 \\
\hline
\end{tabular}

Note: Tg - transgression, $h_{p}$ - the degree of phenotypic dominance of the trait

Table 3

The grain yield from areas of hybrid populations $F_{2}-F_{4}$ of winter wheat, obtained by purposeful selection in 2018-2020

\begin{tabular}{ccccc}
\hline \multirow{2}{*}{ Reproduction in 2020 } & \multicolumn{3}{c}{ Harvest, c/ha } \\
\cline { 2 - 5 } & $\mathbf{2 0 1 8}$ & $\mathbf{2 0 1 9}$ & $\mathbf{2 0 2 0}$ & Average \\
\hline 4952 & 35.7 & 60.0 & 55.5 & $\mathbf{5 0 . 4} \pm 7.5$ \\
4956 & 30.8 & 55.0 & 52.0 & $45.9 \pm 7.6$ \\
4958 & 21.2 & 53.5 & 53.5 & $42.7 \pm 10.8$ \\
4968 & 35.9 & 54.0 & 50.5 & $46.8 \pm 5.5$ \\
4969 & 35.9 & 54.0 & 56.0 & $48.6 \pm 6.4$ \\
4971 & 41.9 & 58.0 & 56.0 & $\mathbf{5 2 . 0} \pm \mathbf{5 . 1}$ \\
4973 & 37.9 & 56.0 & 61.5 & $\mathbf{5 1 . 8} \pm \mathbf{7 . 1}$ \\
4976 & 40.9 & 59.0 & 59.5 & $\mathbf{5 3 . 1} \pm \mathbf{6 . 1}$ \\
4978 & 26.8 & 57.0 & 62.0 & $48.6 \pm 11.0$ \\
4980 & 36.9 & 56.5 & 70.0 & $\mathbf{5 4 . 5} \pm \mathbf{9 . 6}$ \\
4982 & 38.1 & 64.5 & 60.5 & $\mathbf{5 4 . 4} \pm \mathbf{8 . 2}$ \\
4983 & 22.7 & 57.0 & 53.5 & $44.4 \pm 10.9$ \\
4987 & 38.3 & 64.0 & 56.5 & $\mathbf{5 2 . 9} \pm \mathbf{7 . 6}$
\end{tabular}

Note: yield of genotypes that is higher than the average yield of good lines.

The analysis of the results showed that the yield of winter wheat depends on environmental factors. On average, high yields of populations were observed in 2019 and 2020 at 57.6 and $57.5 \mathrm{c} /$ ha, respectively. Among the studied hybrid populations, the highest yields were found in the following ones: 4952, 4971, 4973, 4976, 4980, 4982 and 4987. In others, this figure differs from the average annual value significantly. The largest deviations from the average yield were found in 4958, 4978 and 4983, which indicates their instability in crop formation when changing growing conditions (Table 4).

Hybrid populations 4971 and 4976, which have the highest indicators of genetic stability (50.0 and 50.2) and homeostaticity (19.1 and 14.3), respectively, were selected from the studied hybrid populations $F_{2}-F_{4}$ by the lowest indicators of stress resistance $(-16.1$ and -18.6$)$ and variation (16.9 and 19.9). These combinations have the great breeding value.

In 2018-2020 of hybrid material $F_{5}$ and $F_{6}$ of the Comparative Test, the best families that met the criteria and direction of selection were tested in the phase of milk-wax ripeness. Thus, the use of the pedigree method is the most effective method, which minimizes the homozygosity of the lines in the early stages of the selection process, bringing them to the assessment of the yield. As a result, the selected families were reaped and threshed. After rejection, the selected linear material was sown on plots of $10 \mathrm{~m}^{2}$ in Control, Preliminary and Competitive testing. The final evaluation 
of the elite winter wheat lines was performed after harvesting and compared with the productivity standard. After rejection, there were 4 combinations in the composition of 11 lines, which were tested during 2018-2020 (Table 5).

Table 4

The adaptive traits and selection value of hybrid populations $F_{2}-F_{4}$ of winter wheat in 2018-2020

\begin{tabular}{|c|c|c|c|c|c|}
\hline \multirow{2}{*}{ Reproduction in 2020} & \multicolumn{4}{|c|}{ The parameters of adaptibility } & \multirow{2}{*}{$S c$} \\
\hline & $Y 2-Y 1$ & $(Y 1+Y 2) / 2$ & $V, \%$ & Hom & \\
\hline 4952 & -24.3 & 47.9 & 25.7 & 8.1 & 30.0 \\
\hline 4956 & -24.2 & 42.9 & 28.7 & 6.6 & 25.7 \\
\hline 4958 & -32.3 & 37.4 & 43.6 & 3.0 & 16.9 \\
\hline 4968 & -18.1 & 45.0 & 20.5 & 12.6 & 31.1 \\
\hline 4969 & -20.1 & 46.0 & 22.8 & 10.6 & 31.2 \\
\hline 4971 & -16.1 & 50.0 & 16.9 & 19.1 & 37.5 \\
\hline 4973 & -23.6 & 49.7 & 23.8 & 9.2 & 31.9 \\
\hline 4976 & -18.6 & 50.2 & 19.9 & 14.3 & 36.5 \\
\hline 4978 & -35.2 & 44.4 & 39.2 & 3.5 & 21.0 \\
\hline 4980 & -33.1 & 53.5 & 30.6 & 5.4 & 28.7 \\
\hline 4982 & -26.4 & 51.3 & 26.2 & 7.9 & 32.1 \\
\hline 4983 & -34.3 & 39.9 & 42.5 & 3.0 & 17.7 \\
\hline 4987 & -25.7 & 51.2 & 25.0 & 8.2 & 31.7 \\
\hline
\end{tabular}

Note: Y2-Y1 - stress resistance; $(Y 1+Y 2) / 2$ - genetic flexibility; V-variability; Hom - homeostaticity; Sc - selection value

Table 5

The average grain yield from areas of winter wheat lines during 2018-2020

\begin{tabular}{ccccc}
\hline \multirow{2}{*}{ Reproduction in 2020 } & \multicolumn{3}{c}{ Harvest, c/ha } \\
\cline { 2 - 5 } & $\mathbf{2 0 1 8}$ & $\mathbf{2 0 1 9}$ & $\mathbf{2 0 2 0}$ & Average \\
\hline 4192, UK 9798/18 & 85.0 & 96.3 & 90.1 & $\mathbf{9 0 . 5} \pm \mathbf{3 . 3}$ \\
4193, UK 9804/18 & 91.0 & 91.0 & 80.9 & $\mathbf{8 7 . 6} \pm \mathbf{3 . 4}$ \\
4207, UK 1254/18 & 80.8 & 86.7 & 78.0 & $81.8 \pm 2.6$ \\
4208, UK 1255/18 & 78.5 & 85.0 & 77.7 & $80.4 \pm 2.3$ \\
4209, UK 1256/18 & 77.5 & 87.7 & 78.0 & $81.1 \pm 3.3$ \\
4211, UK 9844/18 & 85.0 & 94.3 & 74.9 & $84.7 \pm 5.6$ \\
4212, UK 9855/18 & 85.0 & 89.3 & 83.5 & $\mathbf{8 5 . 9} \pm \mathbf{1 . 7}$ \\
4219, UK 2614/18 & 84.0 & 90.7 & 89.3 & $\mathbf{8 8 . 0} \pm \mathbf{2 . 0}$ \\
4220, UK 2615/18 & 87.0 & 92.3 & 82.1 & $\mathbf{8 7 . 1} \pm \mathbf{2 . 9}$ \\
4221, UK 2621/18 & 93.0 & 91.0 & 88.3 & $\mathbf{9 0 . 8} \pm \mathbf{1 . 4}$ \\
4222, UK 2641/18 & 91.0 & 89.7 & 84.8 & $\mathbf{8 8 . 5} \pm \mathbf{1 . 9}$ \\
Average & $85.3 \pm 1.5$ & $90.4 \pm 1.0$ & $82.5 \pm 1.6$ & $86.0 \pm 1.1$
\end{tabular}

Note: yield of genotypes that are higher than the average yield of good lines.

These data show that the highest average yield of the studied lines $90.4 \mathrm{c} /$ ha was obtained in 2019. There was a noticeable stability of this indicator among the selected material for three years. There are 7 lines (UK 9798/18, UK 9804/18, UK 9855/18, UK 2614/18, UK 2615/18, UK 2621/18 та UK 2641/18), the average yield of which is at the level of $86.0 \pm 1.1$ or exceeds it.

When creating new varieties, indicators of adaptability are taken into account along with the main feature - productivity. Therefore, the parameters of adaptability and their selection value were calculated for each line (Table 6).

The minimum value of the stress resistance index was observed in the lines of UK 2621/18 $(-4.7)$ and UK 9855/18 (-5.8), which indicates their high resistance to stressors compared to other studied lines. High values of the genetic flexibility index were found in the lines of UK 9798/18 (90.7) and UK 2621/18 (90.7), which indicates the compliance of the selected genotypes with envi- 
ronmental factors. Lines UK 2621/18 $(V=2.6 \%$, Hom =1416.0) and UK 9855/18 $(V=3.5$, Hom=1008.0) have high levels of homeostasis and low variability, which characterize the resistance to variable environmental conditions. High selection value is represented by the lines of UK 9855/18 and UK $2621 / 18$ as the most adaptive and plastic to medium and adverse environmental conditions $(b<1)$.

Table 6

The adaptive traits and selection value of winter wheat lines in 2018-2020

\begin{tabular}{|c|c|c|c|c|c|c|}
\hline \multirow{2}{*}{ Reproduction in 2020} & \multicolumn{4}{|c|}{ The parameters of adaptibility } & \multirow{2}{*}{$S c$} & \multirow{2}{*}{$b$} \\
\hline & $Y 2-Y 1$ & $(Y 1+Y 2) / 2$ & $V, \%$ & Hom & & \\
\hline 4192,UK9798/18 & -11.3 & 90.7 & 6.3 & 264.6 & 79.85 & 0.74 \\
\hline 4193,UK9804/18 & -10.1 & 86.0 & 6.7 & 195.6 & 77.91 & 0.72 \\
\hline 4207,UK1254/18 & -8.7 & 82.4 & 5.4 & 393.4 & 73.62 & 0.75 \\
\hline 4208,UK1255/18 & -7.3 & 81.4 & 5.0 & 598.0 & 73.50 & 0.76 \\
\hline 4209,UK1256/18 & -10.2 & 82.6 & 7.1 & 320.4 & 71.64 & 0.78 \\
\hline 4211,UK9844/18 & -19.4 & 84.6 & 11.5 & 75.3 & 67.30 & 0.80 \\
\hline 4212,UK9855/18 & -5.8 & 86.4 & 3.5 & 1008.0 & 80.35 & 0.73 \\
\hline 4219,UK2614/18 & -6.7 & 87.4 & 4.0 & 547.8 & 81.50 & 0.71 \\
\hline 4220,UK2615/18 & -10.2 & 87.2 & 5.9 & 295.7 & 77.50 & 0.74 \\
\hline 4221,UK2621/18 & -4.7 & 90.7 & 2.6 & 1416.0 & 86.18 & 0.68 \\
\hline 4222,UK2641/18 & -6.2 & 87.9 & 3.7 & 647.4 & 82.47 & 0.70 \\
\hline
\end{tabular}

Note: Y2-Y1 - stress resistance; $(Y 1+Y 2) / 2$ - genetic flexibility; V-variability; Hom - homeostaticity; Sc - selection value; $b$-yield regression coefficient; indicators that have been seen and deserve attention

A line UK 1182/17, which was grown in areas of competitive testing and reproduction of new non-zoned varieties, was created using a purposeful method of pedigree in each link of the selection process. In 2020, it was submitted for consideration to the State Variety Testing under the name - «Blahovishchenska» variety (application form under No. 20012001) (Fig. 3).

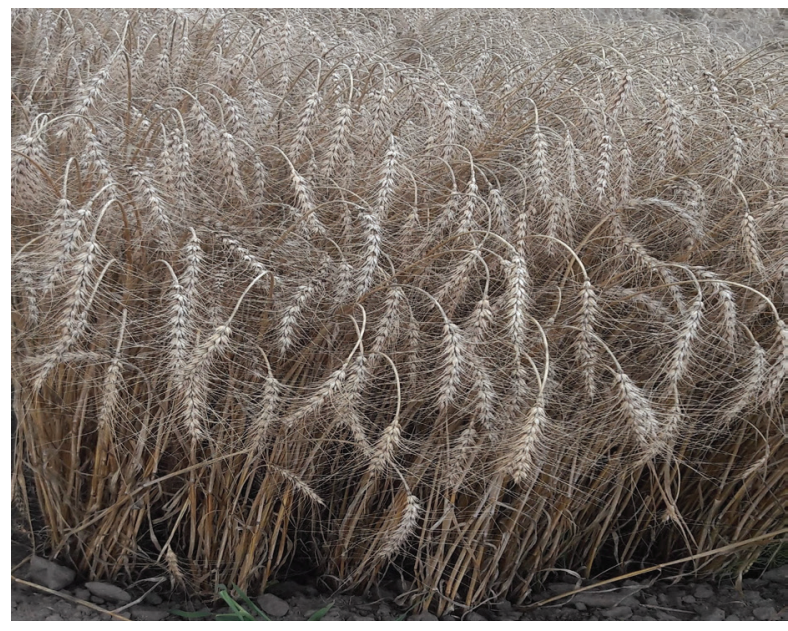

Fig. 3. View of winter wheat on the plots of the «Blahovishchenska» variety

The winter wheat variety was created by individual multiple selection of an elite plant from the hybrid population. The average yield of the new variety during the test years was $90.8 \mathrm{c} / \mathrm{ha}$ with a surcharge to the productivity standard of $6.3 \mathrm{c} / \mathrm{ha}$. It has high rates of frost and drought resistance, is resistant to lodging, major diseases and grain germination in the ear. The variety of plants of «Blahovishchenska» is erythrospermum, it is medium-sized, medium-early and is strong wheat by the quality of grain (protein amount $13.5-14.0 \%$, gluten $-30-35 \%$ ).

Thus, the possibility of a targeted selection of genotypes with valuable traits at the early stages of the breeding process is one of the most basic features of the pedigree method. It allows 
you to study the change in inheritance and the genetic structure of the interaction of traits. In the early generations, the breeder completes the selection of individual plants, and in later generations, the traits of the lines. Taking into account the fact that the yield is characterized by low heredity [23], the pedigree method minimizes the heterozygosity of lines in realizing the genetic potential of productivity. This makes it possible to speed up the selection process of creating varieties with high indicators of yield, adaptability and grain quality.

\section{Conclusions}

Screening of valuable features of linear material of winter wheat was studied. Lines in each link of the selection process, which have high indicators of productive and adaptive traits are separated: of $F_{1}$ hybrids, grain weight of 1 ear has the highest degree of transgression (28.9\%) and complete dominance of the trait in the main crosses and in combinations of the special program (25.0\%); of the studied hybrid populations $F_{2}-F_{4}$ according to the lowest stress resistance ( -16.1 and -18.6) and variation (16.9 and 19.9), combinations 4971, 4976 have the great breeding value; of Control, Preliminary and Competitive testing lines, UK 2621/18 $(V=2.6 \%$, Hom=1416.0) and UK 9855/18 $(V=3.5$, Hom $=1008.0)$ are the most adaptable and flexible to moderate and unfavorable environmental conditions $(b<1)$.

It is established, that the method of pedigree is the most effective method of continuous individual selection. Its use allows to create a source material with high productivity, resistance to disease and adverse environmental factors.

Created by the pedigree method, the «Blahovishchenska» (Kiev, Ukraine) winter wheat variety, which underwent the State test in 2020, is erythrospermum variety. It is medium-sized, medium-early by ripeness, has high yields (exceeding the standard by $6.3 \mathrm{c} / \mathrm{ha}$ ), adaptability, resistance to major diseases and lodging and is strong wheat by grain quality (protein amount 13.5-14.0\%, gluten $30-35 \%$ ).

\section{References}

[1] Havrylyuk, V. M., Vakulenko, V. V. (2020). Plastychnist vitchyznianoho pokhodzhennia. Zerno, 3 (168), 64-71.

[2] Orliuk, A. P. (2012). Henetyka pshenytsi z osnovamy selektsii. Kherson: Ailant, 436. Available at: http://www.ksau.kherson.ua/ lib-ksau/orlyuk a.p._genetyka pshenyci. vystavka_2012.pdf

[3] Kolesnikova, N. D., Verdish, M. B., Shukailo, S. P. (2014). Obgruntuvannia faktoriv vplyvu na urozhainist sortiv ozymoi miakoi pshenytsi v zoni pivdennoho stepu Ukrainy. Zroshuvane zemlerobstvo, 61, 80-84.

[4] Sultana, H., Ali, N., Iqbal, M. M., Khan, A. M. (2009). Vulnerability and adaptability of wheat production in different climatic zones of Pakistan under climate change scenarios. Climatic Change, 94 (1-2), 123-142. doi: http://doi.org/10.1007/s10584-009-9559-5

[5] Popov, S., Avramenko, S., Tsekhmeistruk, M., Manko, K., Glubokiy, O. (2014). Adaptatyvni tekhnolohii dlia vyroshchuvannia. Ahrobiznes syohodni. Available at: http://agro-business.com.ua/agro/ahronomiia-sohodni/item/480-adaptatyvni-tekhnolohii-dlia-vyroshchuvannia.html

[6] Dmytrenko, V. P., Odnolyetok, L. P., Krivoshein, O. O., Krukivska, A. V. (2017). Development of the methodology of estimating of agricultural crop yield potential with consideration of climate and agrophytotechnology impact. Ukrainian hydrometeorological journal, 20, 52-60.

[7] Tkachyk, S. O. (Ed.). (2014). Metodyka provedennia ekspertyzy sortiv roslyn hrupy zernovykh, krupianykh ta zernobobovykh na prydatnist do poshyrennia v Ukraini (PSP). Kyiv: Nilat-LTD, 81.

[8] Riabchun, N. I. (2004). Zymostiikist ozymoi pshenytsi ta metody yii otsinky pry selektsii novykh sortiv. Zbirnyk naukovykh prats SHI, 6, 68-75.

[9] DSTU 4749:2007. Pshenytsia ozyma. Metod vyznachannia morozostiikosti sortiv (2008). Kyiv: Derspozhivstandart of Ukraine, 4-8.

[10] Trybel, S. O., Hetman, M. V., Stryhun, O. O., Kovalyshyna, H. M., Andriushchenko, A. V. (2010). Metodolohiia otsiniuvannia stiikosti sortiv pshenytsi proty shkidnykiv i zbudnykiv khvorob. Kyiv: Kolobih, 392.

[11] Boeven, P. H. G., Zhao, Y., Thorwarth, P., Liu, F., Maurer, H. P., Gils, M. et. al. (2020). Negative dominance and dominance-by-dominance epistatic effects reduce grain-yield heterosis in wide crosses in wheat. Science Advances, 6 (24). doi: http://doi.org/10.1126/sciadv.aay4897

[12] Voskresenskaya, G. S., Shpota, V. I. (1967). Transgressiya priznakov u gibridov Brassica i metodika kolichestvennogo ucheta etogo yavleniya. DAN SSSR, 7, 18-20. 
[13] Fischer, R. A., Rebetzke, G. J. (2018). Indirect selection for potential yield in early-generation, spaced plantings of wheat and other small-grain cereals: a review. Crop and Pasture Science, 69 (5), 439. doi: http://doi.org/10.1071/cp17409

[14] Kondratenko, E. P., Egushova, E. A., Konstantinova, O. B., Pikulina, O. I., Tyukalo, G. N. (2014). Otsenka urozhainosti, ekologicheskoi stabilnosti i plastichnosti novykh sortov ozimoi pshenitsy v usloviyakh lesostepnoi zony kemerovskoi oblasti. Sovremennye problemy nauki i obrazovaniya, 3. Available at: https://science-education.ru/ru/article/view?id=13390

[15] Demydov, O., Homenko, S., Chugunkova, T., Fedorenko, I. (2019). Productivity and homeostaticity of collection samples of spring wheat. Visnyk Agrarnoi Nauky, 97 (9), 47-51. doi: http://doi.org/10.31073/agrovisnyk201909-07

[16] Gupta, S. C., Kapoor, V. K. (2020). Fundamentals of mathematical statistics. Sultan Chand \& Sons. Available at: https://www. sultanchandandsons.com/book/61/fundamentals-of-mathematical-statistics

[17] Arkhiv pogody v Kieve (gorod Kiev, Ukraina). Pogoda i klimat. Available at: http://www.pogodaiklimat.ru/weather. php?id=33345

[18] Morgun, V. V. (Ed.) (2017). Fiziolohiia roslyn: dosiahnennia ta novi napriamky rozvytkuiu. Kyiv: Lohos, 672.

[19] Boroyevich, S. (1984). Printsipy i metody selektsii rastenii. Moscow: Kolos, 344.

[20] Löschenberger, F., Fleck, A., Grausgruber, H., Hetzendorfer, H., Hof, G., Lafferty, J. et. al. (2008). Breeding for organic agriculture: the example of winter wheat in Austria. Euphytica, 163 (3), 469-480. doi: http://doi.org/10.1007/s10681-008-9709-2

[21] Grabovets, A. I., Fomenko, M. A. (2018). Massa zerna integralnyi pokazatel adaptivnosti ozimoi pshenitsy pri selektsii na zasukhoustoichivost. Agronomiya i selskoye khozyaystvo, 5 (49), 16-20.

[22] Adhikari, A., Ibrahim, A. M., Rudd, J. C., Baenziger, P. S., Sarazin, J. (2020). Estimation of heterosis and combining abilities of U.S. winter wheat germplasm for hybrid development in Texas. Crop Science, 60 (2), 788-803. doi: http://doi.org/10.1002/ $\csc 2.20020$

[23] Vlasenko, V. A., Kochmarsky, V. S., Kolyuchy, V. T., Kolomiets, L. A., Khomenko, S. O., Solona, V. Y. (2012). Selektsiina evoliutsiia myronivskykh pshenyts. Myronivka, 326.

Received date 01.10.2021

(C) The Author(s) 2021

Accepted date 15.11.2021

This is an open access article

Published date 30.11.2021 under the Creative Commons CC BY license

How to cite: Khomenko, L. (2021). Creation of winter wheat source material with increased adaptive potential to adverse environmental conditions. EUREKA: Life Sciences, 6, 25-33. doi: https://doi.org/10.21303/2504-5695.2021.002188 